\title{
REVIEW
}

\section{Immunology and immunotherapy approaches for prostate cancer}

\author{
E Elkord \\ CRUK Immunology Department, Paterson Institute for Cancer Research, University of Manchester, Manchester, UK
}

\begin{abstract}
Several mechanisms that impair the immune response to promote tumour progression are reported. These mechanisms aim to reduce the ability of antigen-presenting cells to present antigen and activate naïve $T$ cells to support an active immune response or to create a suppressive environment that induce non-functional tumour-associated antigen-specific T cells. Prostate cancer (PC) alone accounts for $33 \%$ of incident cancer cases and about $9 \%$ of all cancer-related deaths among men in the USA during 2006. Whereas androgen deprivation has remained the first line of therapy for advanced $P C$, other therapies are still required due to progression to an androgen-resistant state and eventually loss of control in patients receiving hormonal therapy. Immunotherapy seems to be a promising approach to enhance tumour-specific T-cell responses in different cancers including prostate. More importantly, clinical trials in advanced PC patients have shown that immunotherapy may generate significant clinical responses. Immunology and immunotherapy aspects of PC with focus on prostate-specific antigen will be presented.

Prostate Cancer and Prostatic Diseases (2007) 10, 224-236; doi:10.1038/sj.pcan.4500964; published online 10 April 2007
\end{abstract}

Keywords: prostate cancer; immunotherapy; prostate-specific antigen; dendritic cells

\section{Tumour immunology}

\section{Overview}

Although William Coley observed the spontaneous regression of a soft tissue sarcoma in patients having acute bacterial infection more than a century ago, the concept of anticancer vaccines and the immunotherapy of cancer has only lately become accepted. ${ }^{1}$ However, the first apparent indication that metastatic human cancers could be eliminated using immunological manipulations came from studies of the administration of autologous lymphokine-activated killer cells and interleukin 2 (IL-2) to patients with metastatic melanoma, colon cancer or renal-cell cancer. ${ }^{2}$ Following a considerable debate as to whether the immune system can recognize and eliminate tumour cells, recent evidence suggests that immune cells can protect against the development of tumours. ${ }^{3,4}$ Nevertheless, the majority of the progress in tumour immunology has been made in the more immunogenic tumours such as melanoma, lymphoma and renal cell carcinoma, whereas a limited success has been achieved with all other less immunogenic cancers. Cancer immunotherapy approach concentrates on killing the tumour cells through various effector cells of the immune system, which include antibody-producing $B$ cells, CD8 ${ }^{+}$CTL, CD4 ${ }^{+}$helper T cells, NK cells and NKT cells. Cancer immunotherapies are made of either active

Correspondence: Dr E Elkord, CRUK Immunology Department, Paterson Institute for Cancer Research, Manchester M20 4BX, UK. E-mail: eelkord@picr.man.ac.uk

Received 4 January 2007; revised 8 February 2007; accepted 28 February 2007; published online 10 April 2007 immunization or passive (adoptive) transfer approaches. Active immunization relies on the in vivo generation of immune cells by an immunizing vector, whereas adoptive therapy involves sensitizing autologous lymphocytes with antitumour reactivity ex vivo, expanding and transferring them into the tumour-bearing host. ${ }^{5}$

\section{T-cell stimulation by dendritic cells}

In vitro, dendritic cells (DC) activate $\mathrm{CD}^{+} \mathrm{T}$ cells directly in the absence of $\mathrm{CD} 4{ }^{+}$T cells. $^{6-8}$ They can also induce the generation of antigen-specific CTL from naïve precursors. ${ }^{9,10}$ Furthermore, injection of mice with DC loaded with different antigens such as peptides, proteins, virally encoded antigens, DNA and RNA induced strong CTL responses in vivo. ${ }^{11}$ However, inducing CD8 ${ }^{+}$T-cell responses in vivo requires $\mathrm{CD}^{+}{ }^{+}$T-cell help. ${ }^{12} \mathrm{CD} 40$ ligation on antigen-presenting cells (APCs) by CD40L on $\mathrm{CD}^{+}{ }^{+}$T cells was found to be necessary to induce CD8 ${ }^{+}$ $\mathrm{T}$ cell priming by APC. ${ }^{13,14}$ In DC-T cell interaction (shown in Figure 1), a conditioned DC can be a temporal bridge between a CD4 ${ }^{+}$T-helper cell and a T-killer cell. ${ }^{15}$ $\mathrm{DC}$ become competent to prime $\mathrm{CD} 8^{+} \mathrm{T}$ cells once they are licensed by $\mathrm{CD}^{+} \mathrm{T}$ cells. Therefore, the same DC may interact with $\mathrm{CD}^{+} \mathrm{T}$ cells and $\mathrm{CD}^{+} \mathrm{T}$ cells simultaneously or sequentially. ${ }^{16}$

There are three possible T-cell fates under different conditions of TCR engagement. ${ }^{17}$ The costimulatory signal received by the interaction of the costimulatory molecules (CD80 and CD86) on the APC with the costimulatory receptor (CD28) on the T cell is necessary for inducing T-cell activation, cytokine production, proliferation and differentiation. Such interaction may play a role in the regulation of type I versus type II T-cell 


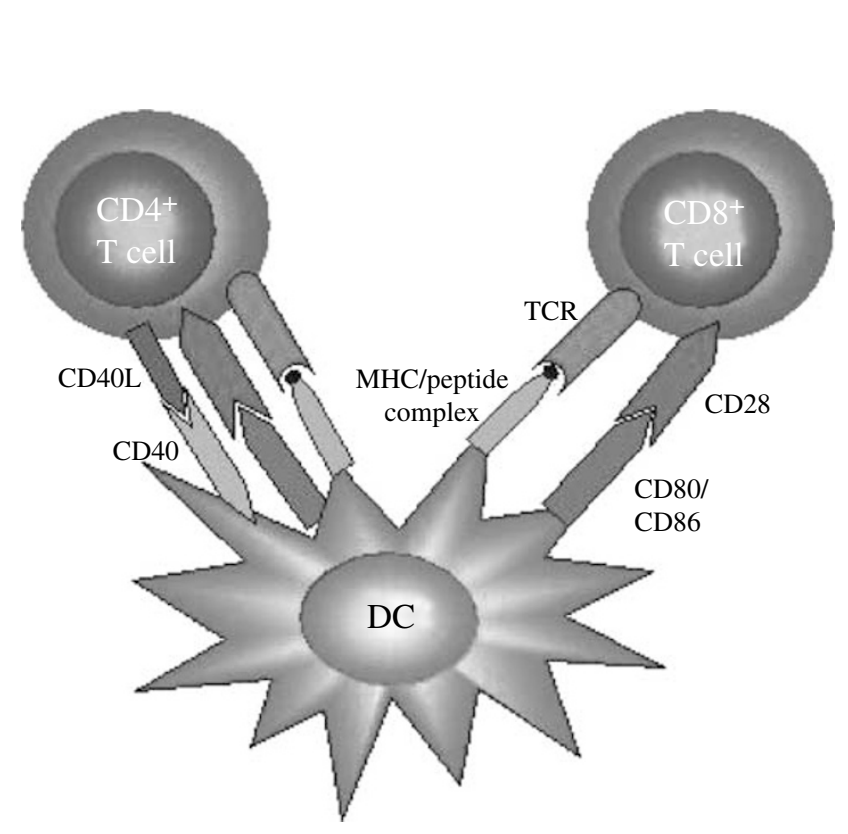

Figure 1 Simplified diagram showing DC-T cell interaction. In addition to the engagement of TCR with MHC-peptide complex (signal one), further signals are needed to stimulate the T cell (signal two). CD80 and CD86 expressed on DC are the ligands for CD28 on $\mathrm{T}$ cells. This ligation is essential to prevent tolerance. CD40L expressed on $\mathrm{CD} 4^{+} \mathrm{T}$ cells enhances the activation of $\mathrm{DC}$ via CD40L-CD40 interaction. Ligation of adhesion molecules stabilizes the immunological synapse and plays a critical role in the signalling required to initiate a primary immunological response.

development (Th1 versus Th2) as CD80 was found to promote Th1 responses, whereas CD86 activated the development of Th2 responses. ${ }^{18,19}$ In the absence of CD28 ligation, T cells become apoptotic or unresponsive, and this emphasizes the importance of such signals in inducing immune response. After T-cell activation, the subsequent upregulation of CTLA-4 switches off the immune response, leading to cell-cycle arrest and termination of T-cell activation.

\section{Immunological surveillance theory}

The theory of the immune system being responsible for policing the aberrant cells (transforming tumour cells and virus-infected cells) in the body was primarily established more than 30 years ago by Frank Macfarlane Burnet, who called it immunological surveillance. ${ }^{20}$ This hypothesis proposes that the immune system can recognize and destroy nascent transformed cells that express an antigen recognized by the immune cells. Immunological surveillance theory was abandoned shortly afterwards because of the absence of strong experimental evidence supporting it; and Stutman reported that nude mice (athymic mice that lack $\mathrm{T}$ cells) were comparable to and not more susceptible to chemically induced tumours than immunologically normal controls. ${ }^{21,22}$ However, later observations that nude mice do not completely lack functional T cells, and additionally they still have an intact innate immunity have led to revival of the interest in the role of the immune system in preventing tumours. ${ }^{23,24}$ The immunological surveillance theory was supported by several studies and the contribution of the immune system in developing or preventing cancers can be inferred from certain aspects. First, there are occasional spontaneous regressions of cancers in immunocompetent hosts and higher cancer incidence in immunocompromized patients. $^{3,25}$ Second, animals with defined immunological defects are more susceptible to spontaneous and induced tumours compared to normal animals, with many of these tumours rejected when transplanted into normal hosts. $^{26}$ Specifically, mice lacking interferon gamma (IFN- $\gamma$ ) or IFN- $\gamma$ receptor developed tumours more rapidly and with higher frequency upon their exposure to chemical carcinogen compared to wild-type mice. Therefore, it was concluded that IFN- $\gamma$ forms the centre of a tumour surveillance system that controls both chemically induced and spontaneously arising tumours in mice. ${ }^{27,28}$ Moreover, a high tumour incidence in aged recombinant activation gene 2-deficient mice that lack mature $\mathrm{T}$ and $\mathrm{B}$ lymphocytes was reported. ${ }^{4}$ Third, the immune system is frequently aware of tumours as indicated by accumulation of immune cells at tumour sites (tumour-infiltrating lymphocytes (TILs)), which is correlated with good prognosis. ${ }^{29}$ Fourth, antitumour immune responses can now be directly detected from many patients with cancers using the new available improved technologies. Amplification of such immune responses against cancers showed therapeutic benefits in experimental models and cancer patients. ${ }^{3}$ Although immunosurveillance of transformed cells by the immune system remains one of the most controversial and poorly understood areas in immunology, there is clearly compelling evidence from animal models and human patients that various cells of the immune system can recognize and regulate tumours.

Following the revival of cancer 'immunosurveillance', a broader new term of 'immunoediting' has emerged recently. This concept infers that the immune system not only provides protection against development of cancers but also sculpts the immunogenic phenotypes of tumours that finally appear in immunocompetent hosts. ${ }^{21}$ Cancer immunoediting is a process consisting of the three Es phases of cancer: elimination (i.e., cancer immunosurveillance), equilibrium and escape. ${ }^{30}$ The elimination phase can destroy a significant percentage of transformed cells but some cells resist immune surveillance destruction. A period of latency extending from the end of the elimination phase to the beginning of the escape phase and the manifestation of clinically detectable malignancy constitutes the equilibrium phase. Edited transformed cells surviving the equilibrium phase go through the escape phase, and tumour growth continues without any restrictions from the immune system. ${ }^{30}$ Indeed, the cancer immunoediting process may not always proceed in the previously described sequence, and it may be terminated in the elimination phase if immunosurveillance succeeds in destroying the growing tumour. Clearly, the immune system can facilitate the development of cancer by sculpting the immunogenic phenotype of tumours as they develop. ${ }^{30}$ Therefore, the immune system plays a dual role in the complex interactions between tumours and hosts.

\section{Human tumour antigens recognized by $T$ cells}

Antitumour immune responses appear to be widely mediated by $\mathrm{T}$ cells rather than by antibodies. ${ }^{31}$ More than 10 years after the landmark studies of Boon ${ }^{32}$ and Rosenberg, $^{33}$ the expression of certain antigens on 
human cancer cells that can be specifically targeted by cellular immunity, nowadays forms a scientific justification for the design and clinical testing of antigen-specific cancer immunotherapies. ${ }^{34}$ Detection of tumour-associated antigens (TAA) has stimulated research into the development of immunotherapies to mediate regression of established tumours.

Identification of CTL epitopes presented by major histocompatibility complex (MHC) class I molecules on tumour cells is vital for the design of active immunotherapy. Many antigens presented on MHC class I molecules for $\mathrm{CD}^{+} \mathrm{T}$ cells have been identified using any of the four characterized approaches. The 'genetic approach' is based on the transfection of cDNA libraries from tumour cells into target cells expressing the appropriate human leukocyte antigen (HLA) molecule, and then screening transfected cells for stimulating $\mathrm{CD}^{+}$T-cell clones from cancer patients. ${ }^{35-37}$ Alternatively, the 'peptide-elution approach' involves the biochemical elution of peptides from the binding cleft of tumour HLA molecules, and pulsing these peptides onto APC to test their ability to sensitize target cells for lysis by specific antitumour lymphocytes. ${ }^{38-39}$ Peptides with potential reactivity are sequenced using mass spectrometry. A third technique often referred to as the 'reverse immunology approach' has been used successfully to predict peptide sequences from oncogenes- or tumour-associate proteins using known HLA-anchor motifs, followed by an in vitro investigation of the ability of the predicted synthetic peptides to stimulate $\mathrm{T}$ lymphocytes. ${ }^{40,41}$ The serological identification of antigens by recombinant expression cloning '(SEREX)' has also been used to identify new antigens.

Human tumour antigens recognized by $\mathrm{T}$ cells can be classified into six groups: (1) Class I HLA-restricted cancer/testis antigens - all these antigens were found to be expressed on normal spermatocytes and spermatogonia of testis, and they include MAGE, BAGE, GAGE and NY-ESO-1. ${ }^{43}$ (2) Class I HLA-restricted, tissue-specific differentiation antigens - these antigens are shared between tumours and the normal tissue from which the tumour arose, and thus they can only be expressed in normal and malignant cells of the same lineage such as melanocytes and tissue of the prostate gland. ${ }^{44}$ (3) Class I HLA-restricted widely expressed antigens - genes encode widely expressed tumour antigens that are detected in many normal and tumour tissues with no favoured expression on a certain cancer; for example, carcinoembryonic antigen, which is expressed on colon, breast, lung and gastric carcinomas and on normal gastrointestinal and embryonic tissue. ${ }^{45}$ (4) Class I HLArestricted, tumour-specific antigens - they are unique tumour antigens that arise from mutations of normal genes such as cyclin-dependent kinase 4 and $\beta$-catenin. $^{46,47}$ (5) Class II HLA-restricted antigens - identification of tumour epitopes recognized by $\mathrm{CD}^{+} \mathrm{T}$ lymphocytes can be a critical approach for improving antitumour immune responses. The first epitope presented on HLA class II molecules and able to induce $\mathrm{CD}^{+}{ }^{-}$T-cell responses was identified in 1994 from melanoma-associated antigen tyrosinase. ${ }^{48}$ (6) Fusion proteins - the molecular mechanism of carcinogenesis may involve translocation of chromosomes, mainly in leukaemia, which leads to formation of fusion genes and consequently fusion proteins. ${ }^{43}$
The goal of the development of cancer vaccines is to break tolerance of the immune system for antigens expressed mainly or exclusively by the tumour cells. However, most of the identified TAA are self-proteins and as a result are poorly immunogenic due to immune tolerance. This tolerance requires to be reversed using optimal immunization strategies in an attempt to harness the immune responses to attack and kill the tumours. Additionally, tumour-expressed antigens recognized by $T$ cells are not necessarily tumour specific. For example, MAGE-1, the first human T-cell-recognized tumour antigen, is not only expressed on melanoma cells but also in testis. ${ }^{32}$ Moreover, a single TAA contains epitopes that can be presented on different HLA molecules. For example, the gp100 antigen is presented on HLA molecules A2, A3, A24, Cw8, DR4 and DR15, where the tyrosinase antigen is presented on A1, A2, A24, B44, DR4 and DR15. ${ }^{49}$ A large number of therapeutic vaccination trials have been performed after the identification of several TAA recognized on human tumours by autologous $\mathrm{T}$ lymphocytes. ${ }^{50}$ However, the majority of these clinical trials were performed in melanoma patients using TAA-based vaccinations. Vaccine-induced T-cell responses were detected in melanoma patients without reporting any clinical responses in some trials, ${ }^{51,52}$ whereas clinical responses including stabilization of disease, partial and even complete tumour regression were reported in other trials. ${ }^{53-57}$ Although most immunotherapy studies have been performed in melanoma patients, the discovery of antigens on other tumours and the principles gained from melanoma patients can lead to the expansion of these studies to patients with more common tumours. ${ }^{58}$

\section{Mechanisms limiting cancer regression}

The fact that antigenic tumours can grow successfully in the host indicates that there are limitations in the competence of immune surveillance in tumour control, and cancers are able to evade the immune surveillance. ${ }^{59}$ It is not surprising that spontaneously arising tumours are rarely rejected by $\mathrm{T}$ cells, as they perhaps lack either distinctive antigenic peptides or the adhesion or costimulatory molecules that are needed to generate a T-cell response. $^{60}$

Tumours can evade detection and elimination by immune surveillance in a variety of ways that limit the effectiveness of immune stimulation. First, some cancers, such as colon, prostate and cervix, can evade immune surveillance by loss of expression of MHC class I molecules. ${ }^{61-63}$ Tumour cells can no longer be recognized by CTL when they lose the expression of all MHC class I molecules, although these cells might be more susceptible to NK cells. ${ }^{60}$ Second, tumour cells usually lack expression of costimulatory molecules (B7.1 and B7.2) and are thus poor inducers of T-cell activation. Therefore, inadequate costimulation of tumour-reactive $\mathrm{T}$ cells may lead to weak antitumour immune responses and as a result to tumour progression. ${ }^{64}$ Third, the tumour itself may be an active contributor in causing immune suppression by producing local immunosuppressive cytokines. ${ }^{49}$ Vascular endothelial growth factor, produced by almost all tumour cells, dramatically affects the ability of haemopoietic progenitor cells to differentiate into functional DC. ${ }^{65,66} \mathrm{DC}$, which play a central role 


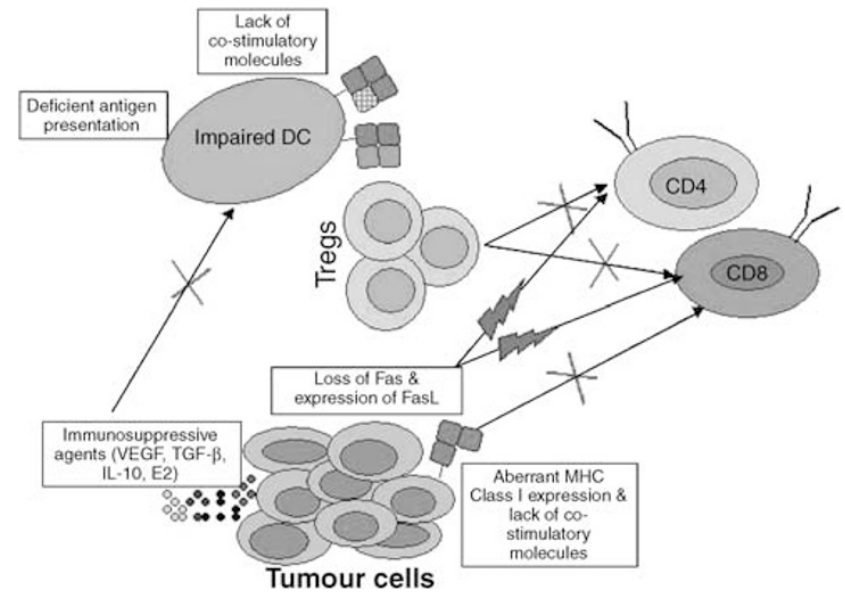

Figure 2 Tumour escape mechanisms. There are different mechanisms that induce tumour escape from an active immune response as summarized in the section of mechanisms limiting cancer regression.

in antitumour immunity, are functionally impaired in tumour-bearing animals ${ }^{67,68}$ and in cancer patients ${ }^{69-71}$ probably due to their susceptibility to tumour-mediated immunosuppression. Several tumours, such as melanoma, ovarian carcinoma and B-cell lymphoma have been found to produce the immunosuppressive cytokine IL10 , which can reduce DC development and activity. ${ }^{60,72}$ Moreover, tumour cells are able to produce transforming growth factor- $\beta^{73}$ and prostaglandin E2, ${ }^{74}$ which play a significant role in immunosuppression. Fourth, partial or complete loss of CD95 (Fas) expression on tumour cells may enable them to escape CD95-mediated killing. Tumour cells also express CD95L (FasL) that can lead to an active destruction of $\mathrm{T}$ lymphocytes. ${ }^{75}$ Finally and following the recent interest in regulatory $\mathrm{T}$ cells, tumours may induce immunotolerance against tumour antigen-specific $\mathrm{T}$ cells through tumour-specific $\mathrm{CD} 4{ }^{+}$ Treg cells at tumour sites. ${ }^{76}$ An increase in the frequency of $\mathrm{CD}^{+}{ }^{+} \mathrm{CD} 25^{+} \mathrm{T}$ regulatory cells has been described in the peripheral blood and TILs of patients with different cancers, and this increase has been reported very recently in the tumour and peripheral blood of prostate cancer (PC) patients. ${ }^{77}$ Undoubtedly, growth and evasion of transformed tumour cells, despite their immunogenicity and recognition by the immune system, represents one of the main obstacles in tumour immunology. All known tumour escape mechanisms are summarized in Figure 2.

\section{Assays for monitoring cellular immune responses to cancer immunotherapy}

Using immunological assays to evaluate the number and function of $\mathrm{CD}^{+} \mathrm{T}$ lymphocytes that are able to directly recognize tumour-associated peptides presented by MHC class I molecules on the surface of tumour cells is an essential strategy for cancer immunotherapy. Some of these assays are promising methods for enumerating and characterizing the $\mathrm{T}$-cell response to immunization. These assays include in vivo functional measures, in vitro phenotypic assays and in vitro functional assays; ${ }^{78}$ and herein the in vitro assays will be described.

Recently, it has become possible to directly visualize and enumerate antigen-specific T cells by flow cytometry

using soluble, fluorescently labelled, tetrameric MHCpeptide complexes (shortly named tetramers). ${ }^{79}$ Such a tetrameric complex is produced by four synthetic and biotinylated peptide-folded HLA molecules that are centrally linked by a fluorochrome (mainly phycoerythrin)-conjugated streptavidin molecule. ${ }^{80,81}$ As they are generated in a multivalent (usually tetrameric) form, they are able to bind stably, specifically and avidly to T-cells specific for that peptide, which allows their detection and purification by magnetic beads. Tetramers have been used successfully to detect, enumerate and isolate $\mathrm{CD}^{+} \mathrm{T}$ cells from peripheral blood or lymph nodes that are specific for tumour antigens or control antigens used frequently in immunization protocols. ${ }^{82-85}$ Although tetramers are powerful tools, they have some limitations: they can only be used to detect immune responses to known antigens, and whereas MHC class I tetramers are routinely available, there are some difficulties in synthesizing class II tetramers.

T-cell number and function can be monitored by assays that detect $\mathrm{T}$ cells by their activity such as proliferation, cytotoxicity and cytokine production. Tcell proliferation in response to antigen is used as an indicator of the presence of antigen-specific $\mathrm{T}$ cells. Such proliferation can be measured by ${ }^{3} \mathrm{H}$-thymidine or bromodeoxyuridine (Brdu) incorporation assays. Recently, flow cytometric assays measuring distribution of cell membrane dyes into dividing cells produced during proliferation allows the determination of the precursor frequency of antigen-specific T cells. ${ }^{86}$ Determination of the ability of CD8 ${ }^{+}$CTL to kill tumours using cytotoxicity assays is an important indicator for the in vivo antitumour activity. Such ability is measured by the traditional ${ }^{51} \mathrm{Cr}$-release assay, or alternatively by using some flow cytometric methods based on labelling targets with membrane dye and measuring any cell death within the target population by a viability dye. ${ }^{87-89}$ Cytokine secretion from $\mathrm{T}$ cells in response to antigen stimulation may be detected by measuring either bulk cytokine production using an enzyme-linked immunosorbent assay or multiplexed flow cytometric assays, ${ }^{90}$ whereas cytokine assay at single-cell level can be performed by the enzyme-linked immunospot (ELISPOT) assay. ${ }^{91}$ The ELISPOT technique is a specific and a sensitive tool designed to enumerate individual cytokine-secreting $\mathrm{T}$ cells. The specificity and sensitivity of ELISPOT is derived from using high affinity capturing and detection antibodies. A reliable enumeration of T-cell frequencies is critical for monitoring immune responses for specific cancer vaccines, and detecting IFN- $\gamma$ by ELISPOT assay can be an important tool for the characterization of T-cell effector function. Spiking known numbers of antigen-specific T cells in PBMC preparations proved the reliability of ELISPOT assay. ${ }^{92}$ Moreover, intracellular cytokine staining and flow cytometric analysis can be an additional way of assessing cytokine production at a single-cell level. ${ }^{93}$

\section{Prostate cancer}

Figures and facts

PC affects 1 in 10 men, and 540000 new cases of PC were diagnosed worldwide in 2000 as estimated by the World 
Health Organisation. In Western countries, PC is the most common diagnosed cancer affecting men after middle age, and a leading cause of cancer-related death in men. More specifically, during 2006 in the USA, 234460 new cases of PC and 27350 deaths from the disease are estimated accounting for a full third of the total incident cancer cases in men and $9 \%$ of all deaths. ${ }^{94}$ In the UK, 27149 PC cases were diagnosed in the year 2000, and 9937 PC-related deaths were reported in the year 2002. ${ }^{95}$ PC has traditionally been considered a disease of elderly men, but unfortunately its prevalence is increasing in young men. Indeed, PC continues to be a major public health problem in the Western world, where the number of cases is rising, caused mainly by demographic factors, especially the increasingly elderly population and, more importantly, the increasing number of cases diagnosed following the introduction of prostate-specific antigen (PSA) testing. For example, the annual incidence of PC in the USA increased from an estimated 76000 cases in 1984 to 200000 cases in $1994 .^{96}$

The natural history of PC is not completely understood, as it is not a single disease entity but more a variety of diseases ranging from aggressive to slow growing tumours; and it is often said that most men are more likely to die with PC than from it. ${ }^{97}$ Although the causes of PC are not well known, there are several risk factors that can increase its occurrence, with age as the strongest risk factor. Approximately 5-10\% of all PC cases are believed to have a substantial inherited component. ${ }^{98}$ Ethnicity plays a role in the development of the disease, as its incidence is higher in African Americans (about twice that in white men), and lowest in Asian, American Indians and Hispanic-Latino. ${ }^{99} \mathrm{~A}$ diet high in fat, mainly animal fat, may increase the risk of developing PC. ${ }^{100}$ The clinical features of PC include localized PC (confined within the prostatic capsule), locally advanced PC (cancer extends outside the prostatic capsule) and metastatic PC (PC often metastasizes to the bone and causes pain). Approximately $25 \%$ of patients in the UK have metastatic disease when initially diagnosed. $^{101}$

\section{Prostate-specific antigen}

History and characteristics. In 1970, Ablin et al. ${ }^{102}$ identified two different human prostatic tissue-specific antigens. One of the antigens was identified as prostatic acid phosphatase (PAP), whereas the other remained unnamed. One year later, Hara et al. ${ }^{103}$ identified a protein in seminal fluid, and called it gamma-seminoprotein. In 1979, Wang et al. ${ }^{104}$ managed to characterize and purify this antigen from prostatic tissue and named it PSA.

The human tissue or glandular kallikrein gene family was believed to be composed of only three members (the classical kallikreins), tissue/renal kallikrein (KLK1, its protein hK1), human prostate-specific glandular kallikrein $(K L K 2$, its protein $h K 2)$ and PSA (KLK3, its protein PSA or hK3). ${ }^{105}$ Recently, this group has been expanded to include 15 kallikreins, and all the human kallikrein genes are located at the same chromosomal locus, 19q13.4. ${ }^{106,107}$ Human kallikreins share common features, with a significant homology of $40-80 \%$ on nucleotide and amino acid levels between them. ${ }^{107}$ For example, hK2, another PC marker, shares a 78\% homology with PSA; and $\mathrm{hK} 1$, a kallikrein found in pancreas and renal tissue, shows about $60 \%$ homology with PSA. ${ }^{108,109}$ PSA is expressed as a 261 amino acid preproprotein, with a 17 amino acid signal sequence, a seven amino acid activation peptide and the mature protein of 237 amino acids. ${ }^{110}$ It is made of a single-chain glycoprotein, with a single N-linked carbohydrate side chain which represents approximately $8 \%{ }^{111}$ PSA is produced mainly by epithelial cells of both benign and malignant prostate tissue, and secreted into the lumen of the prostate gland as an inactive 244-amino acid proprotein (pro-PSA), which is activated to PSA by the cleavage of the activation peptide. ${ }^{112}$ It is then secreted into the blood, where it is rapidly bound by protease inhibitors such as $\alpha 1$-antichymotrypsin; however, a fraction is inactivated by proteolysis and circulates as free PSA. Proteolytic inactivation and the cleavage of pro-PSA are less efficient in PC, and as a result the ratio of free-to-bound PSA is reduced in the serum of patients with $P C$, so the ratio can be used as an index to distinguish elevated PSA levels due to cancer or to benign prostatic diseases. ${ }^{113}$ The molecular weight of the free PSA molecule in human seminal plasma and serum is 33 or $34 \mathrm{kDa}$, depending on the source of information. ${ }^{11,114}$ It is an androgenregulated serine protease (proteolytic enzyme) and, like all proteases, it is able to digest and degrade proteins by hydrolysis of the peptide bonds. The known physiological function of PSA is liquefaction of the seminal clot after ejaculation by digesting the seminal vesicle proteins, seminogelin and fibronectin, resulting in increased sperm mobility. ${ }^{115}$ It was believed that female sera are negative for PSA but with the availability of highly sensitive methods for measuring minute amounts of PSA, it was possible to demonstrate that female sera have PSA immunoreactivity consisting mainly of free PSA. ${ }^{116-118}$ The main source of female PSA has been suggested to be the 'female prostate', Skene's glands and ducts, which are located paraurethrally. ${ }^{119-120}$

\section{Utility of the PSA test}

From 1984 to 1990, there was an increase in the diagnostic use of the PSA test (from 5.1. to $66.4 \%$ of incident carcinomas). ${ }^{96}$ Therefore, the introduction of PSA testing leaded to a significant increase in the reported incidence of PC. ${ }^{121}$ The increased use of PSA testing in the UK has resulted in a sharp increase in the number of cases diagnosed with PC. PSA testing is not routinely offered to all men in the UK. A recent study named for short as ProtecT (Prostate testing for cancer and Treatment) has been commenced recently in nine centres in the UK. In this study, men aged over 50 are screened for PC by measuring their serum PSA, and three different treatments for localized PC are evaluated. However, the PSA test continues to be a controversial issue regarding its predictive value and specificity in the early detection of PC. PSA is a tissue-specific marker but not a tumour-specific marker in the prostate; therefore, conditions other than cancer, such as benign enlargement of the prostate, prostatitis and lower urinary tract infection can cause elevated PSA levels. ${ }^{122}$ Typically, a PSA value of $4.0 \mathrm{ng} / \mathrm{ml}$ in male serum has been used as the upper limit of the normal range. However, not all 
men with a PSA value higher than $4.0 \mathrm{ng} / \mathrm{ml}$ will have biopsy-confirmed cancer. ${ }^{123}$ More specifically, at least two-thirds of men with elevated PSA levels are not diagnosed with PC at biopsy. ${ }^{97}$ Moreover, biopsy-confirmed cancer was detected in a significant proportion of men with PSA values of $2.5-4.0 \mathrm{ng} / \mathrm{ml}^{124,125}$ Although PSA testing remains controversial, population-based studies propose that PSA screening minimizes PC-related death, and serum PSA measurements are still the most useful biomarker for early detection, clinical staging and therapeutic monitoring of PC. There are some suggested manipulations that might improve the use of PSA in clinical practice: (1) customizingscreening protocols for individuals with high risk to reduce costs; (2) lowering PSA cut-offs to $2.5 \mathrm{ng} / \mathrm{ml}$, for example, may reduce the detection of PC at advanced stages; and (3) the use of different PSA forms may reduce unnecessary biopsies in some men. ${ }^{126}$

Although static PSA serum levels $(>4.0 \mathrm{ng} / \mathrm{ml})$ are commonly used to screen for PC, isolated PSA values have some limitations. For example, static PSA values alone cannot give a complete picture about the behaviour or nature of the disease. In particular, dynamic PSA values such as 'doubling time' can better reflect the disease activity, especially cancer progression or regression. ${ }^{127}$ Doubling time, simply, is the time that a serum PSA value takes to be doubled. Therefore, the shorter the doubling time, the more rapid the rise in PSA level and vice versa. Another alternative measurement for describing the changes in PSA is 'PSA velocity' which refers to the rate of rise in the PSA. ${ }^{128}$ Recently, it has been shown that PSA testing over a period of time is a reliable marker of possible risk of mortality from PC. It was concluded that an increase in the PSA level by more than $2.0 \mathrm{ng} / \mathrm{ml}$ during the year before the diagnosis of cancer might relatively increase the risk of death from PC even when radical prostatectomy is performed. $^{129}$

\section{Immunotherapy for PC}

Rationale. The first case of a patient receiving immunotherapy for PC was reported in 1962, in which Coley's toxin resulted in pain relief and an increase in weight in that patient. ${ }^{130}$ The recovery probability of early localized PC by radical prostatectomy or radical radiotherapy is quite high; however, between 35 and $61 \%$ of patients undergoing such treatment modalities are later found to have non-organ-confined disease or positive prostatic biopsies. ${ }^{131-133}$ As a result, a significant proportion of patients seem to be left with residual disease, and currently no adjuvant or salvage therapy has been confirmed to be of promising benefit for treating these patients. Whereas androgen deprivation has remained the first line of therapy for advanced PC, other therapies are still required due to progression to an androgenresistant state and eventually loss of control in patients receiving hormonal therapy. Certainly therefore, new and improved therapeutic approaches are still required for the management of patients with localized and advanced PC. Immunotherapy is an attractive strategy in light of the potential role of the immune system in PC, which is supported by the significant correlation of TILs with good prognosis; and the ability to harness the immune system for non-immunogenic cancers such as prostate. 134

\section{Prostate-associated antigens recognized by $\mathrm{CD} 8^{+} \mathrm{T}$}

lymphocytes and their application in clinical trials

The identification of antigens expressed by prostate tissue and/or prostate tumour cells that can be recognized by $\mathrm{T}$ lymphocytes paved the way for the development of novel immunotherapeutic approaches for PC. Over the past years, several prostate-specific or PC-associated gene products have been reported including PSA, PAP, prostate-specific membrane antigen (PSMA), prostate stem cell antigen (PSCA) and some others. A number of prostate-associated-derived peptides have been identified, which can activate CTL and consequently lead to the killing of tumour targets by the peptide-specific CTL. The majority of antigens characterized in the prostate represent self-proteins, and consequently they are non-immunogenic and unable to induce immune responses on their own. Furthermore, soluble antigens that circulate in the serum, such as PSA and PAP, are mainly tolerogenic. ${ }^{135}$ Thus, cancer vaccines are being developed in an attempt to stimulate immune responses by generating CTL and/or antibodies from $B$ cells to break the pre-existing tolerance to such antigens.

PSA is a potential target of vaccine therapy for human PC, since it is nearly exclusively expressed on prostatic epithelial cells, and its expression is conserved in nearly all advanced PC. ${ }^{136-137}$ In some studies, CD8 ${ }^{+}$T-cell responses were induced in vitro to specific peptides derived from PSA protein. Following repeated in vitro stimulation of peripheral blood lymphocytes from a normal HLA-A2 + volunteer, Xue et al. ${ }^{38}$ generated CTL with specificity to one synthetic nonamer (9-mer) peptide corresponding to residues 146-154 of human PSA protein and containing a canonical HLA-A2-binding motif. In another study, two synthetic decamer (10-mer) peptides corresponding to residues 141-150 and 154-163 of PSA were able to elicit CTL responses in vitro from normal HLA-A2 + volunteers. ${ }^{139}$ We have recently used tetramers for three PSA-derived peptides to directly quantify PSA-specific CD ${ }^{+} \mathrm{T}$ cells in peripheral blood of non-vaccinated patients with PC and compared with a control group without cancer. ${ }^{89,140}$ An example of visualization of PSA-specific CD8 ${ }^{+}$T cells using tetramer staining is shown in Figure 3. Our studies showed that PSA-specific $\mathrm{CD}^{+} \mathrm{T}$ cells exist at low frequency regardless of the presence of PC. Also our studies demonstrated that the frequency can be amplified by in vitro stimulation with DC pulsed with PSA-derived peptides. A PSA oligoepitope peptide (30-mer, designated PSA-OP) containing motifs for HLA-A2, -A3, -A11 and B53 alleles induced the development of CTL that are able to kill peptide-pulsed TAP-deficient cells and PSApositive PC cells. ${ }^{141}$ Another approach employed the design and use of an agonist epitope by amino acid substitution to certain positions of a PSA-derived peptide in an attempt to enhance the immunogenicity of PSA and improve the killing activity of the expanded CTL. ${ }^{142}$ For lymphocytes grown from patients with PC and stimulated in vitro, specific recognition of one PSA-derived peptide (amino acid residues 141-150) was reported in one patient of seven. ${ }^{143}$ Whereas most 


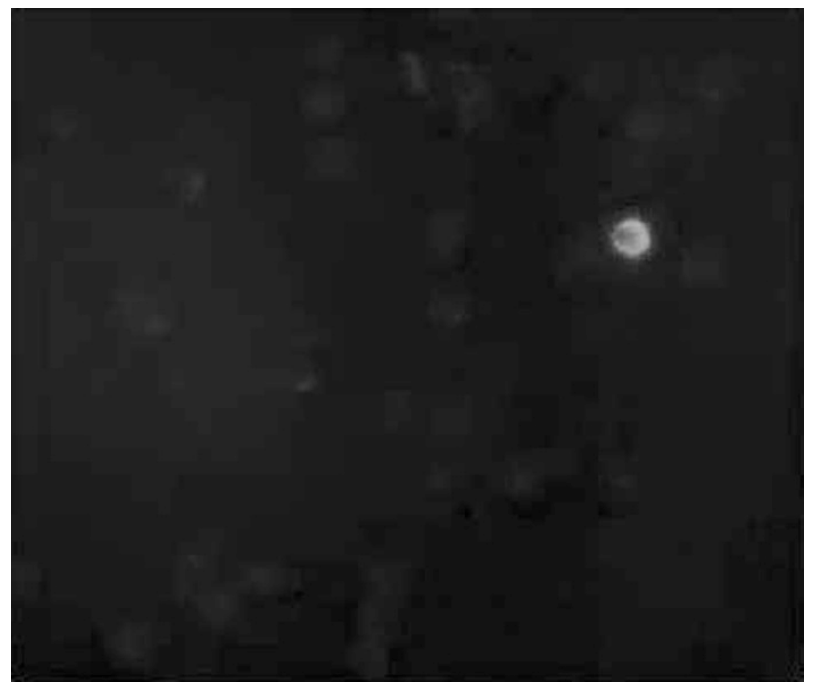

Figure 3 Fluorescence microscopy image of PSA-4 $141-150$-specific $\mathrm{CD}^{+}{ }^{+} \mathrm{T}$ cell. Peripheral blood lymphocytes from a patient with PC were stained with PSA-4/tetramer complex, and a fluorescence image was taken. One PSA-4-specific CD8 ${ }^{+} \mathrm{T}$ cell among several nonspecific (negative) cells is visualized using PSA-4/tetramer staining.

reports have shown that specific $\mathrm{CD}^{+}$CTL were generated by different means of in vitro stimulation, a recent report demonstrated that IFN- $\gamma$-producing $\mathrm{CD}{ }^{+}$ T-cells specific for PSA-derived peptides exist in patients which are antigen experienced, and do not require in vitro stimulation. ${ }^{144}$ These observations made it clear that within the $\mathrm{T}$-cell repertoire there are populations of $\mathrm{T}$ cells specific for PSA-derived peptides, which can be activated by these peptides; and as a result, PSA was used in a number of clinical trials as an immunogen to be given to patients with PC. In a phase I study, six patients who had biochemical recurrence of disease after radical prostatectomy and receiving hormonal therapy were vaccinated with a PSA-expressing recombinant vaccinia virus, and one of these patients had a delay of PSA rise. ${ }^{145}$ In another larger phase I trial, a PSAexpressing recombinant vaccinia virus was administrated to patients with advanced PC, and a stable PSA level was achieved in 14 of 33 men for at least 6 months after primary vaccination. ${ }^{146}$ More recently, the same recombinant vaccinia was given to 42 patients with metastatic PC, and an increase in the number of PSAspecific $T$ cells was reported in some patients. ${ }^{147}$ In a different approach and to increase the effectiveness of recombinant PSA as the immunogen, PSA was prepared in liposomes with lipid A (designated JBT 1001) before vaccination. PSA-reactive $\mathrm{T}$ cells were detected in the peripheral circulation of the majority (8 out of 10) of patients tested. ${ }^{148}$

PSMA is a 750 amino acid membrane-bound protein expressed by prostatic epithelial cells. ${ }^{149}$ Immunogenic, HLA-A2-restricted peptides derived from PSMA protein and capable of stimulating in vitro CTL responses were identified. ${ }^{150,151}$ Some clinical trials made use of the identified PSMA-derived peptides, which were loaded on DC and used to target prostatic epithelial cells. Prostate acid phosphatase is a 354 amino acid glycoprotein expressed on prostatic tissue. ${ }^{152}$ It has been demon- strated that some HLA-A2-restricted peptides derived from PAP have been shown to induce PC-reactive CTL in HLA-A2 + patients with PC. ${ }^{153,154}$ PSCA is a 123 amino acid protein expressed on normal prostatic epithelial cells and retained in advanced PC. ${ }^{55}$ In two studies, different immunogenic, HLA-A2-restricted peptides derived from PSCA were identified and shown to induce PSCA-specific CD8 ${ }^{+}$T-cell responses in patients with PC. ${ }^{156,157}$ Therefore, the recently identified PSCA might be a promising target for immunotherapy of PC.

\section{DC-based PC vaccines}

One of the recent advances in cancer immunotherapy is the use of DC as the vehicle to deliver cancer antigens for an effective in vivo T-cell stimulation. ${ }^{158} \mathrm{DC}$, as the most efficient APCs, have been used to immunize against and target prostate-derived antigens. Usually, in cancer vaccines involving $\mathrm{DC}$ as their vectors, there are two major components: DC isolated and grown from patients, and a specific antigen used to target PC tissue. The source and differentiation status of DC are key factors to be carefully considered in the design of any DC-based cancer vaccines. In some trials, DC were loaded with synthetic peptides to activate peptidespecific CTL, while in others they were exposed to tumour lysates or apoptotic bodies to allow them to present a broad spectrum of TAA, and probably trigger both $\mathrm{CD}^{+}$and $\mathrm{CD}^{+}{ }^{+} \mathrm{T}$ cells. ${ }^{159}$ Another approach involved the transfection of DC with recombinant DNA vectors encoding one or more potential TAA. In addition, use of RNA-pulsed DC vaccine is one of the strategies that have been employed in clinical trials.

Murphy and Tjoa ${ }^{160-164}$ have performed several phase I and II clinical trials of the use of PSMA-derived peptide-pulsed DC for patients with locally advanced or metastatic PC. They loaded monocyte-derived DC with one of two HLA-A2-restricted PSMA-derived peptides (PSM-P1 and PSM-P2), and administered them intravenously. These trials demonstrated the safety and good tolerability of this approach and showed some evidence of inducing $\mathrm{T}$-cell responses. In a group of 51 patients with hormone refractory $\mathrm{PC}$, seven patients exhibited partial responses. In a phase II clinical trial including a group of 37 patients with disease recurrence after primary treatment, 11 responded, with one complete and 10 partial responses. Although the peptides used in these trials were HLA-A2 restricted, some of the responders were not HLA-A2 positive. This might be explained by the possibility of capturing and presenting endogenous antigens by the infused DC, leading to immune responses. Another possibility is that the peptides used may be presented by other HLA molecules, not just HLA-A2. Additionally, the infused DC may induce nonspecific immune responses, leading to clinical benefits. In another vaccination approach targeting also PSMA and possibly modulating DC in vivo, 26 patients with PC were immunized with either a cDNA plasmid encoding either the extracellualr domain of PSMA, an adenoviral vector expressing PSMA, or both in a prime and boost strategy. ${ }^{165}$ The vaccination was well tolerated and no immediate or long-term side effects were reported. All patients who received initial inoculation with the viral vector followed by PSMA plasmid boosts showed signs of immunization as indicated by the 
development of a delayed-type hypersensitivity response.

Autologous DC transfected with PSA mRNA were used to vaccinate 13 patients with metastatic PC. Interestingly, all patients developed PSA-specific T-cell responses suggesting bioactivity of the vaccine in vivo, and vaccination was associated with a reduction in the rate of rise of PSA (PSA velocity) in six patients. ${ }^{166,167}$ Loading of DC with RNA allows endogenous production and processing of antigens. Heiser et al. ${ }^{167}$ demonstrated that transfection of PSA mRNA induces immunogenic PSA expression on DC. Additionally, the application of mRNA to DC may induce the activation of both CD8 ${ }^{+}$ and CD4 ${ }^{+}$T cells. On the other hand, the RNA approach, like loading DC with tumour lysate, may induce potentially toxic autoimmune responses to unknown antigens in the RNA or lysate pool. ${ }^{168}$ Recently, DC loaded with synthetic peptides derived from prostateassociated antigens have been employed in different clinical trials. Twenty-eight patients with locally advanced or metastatic PC were vaccinated with PSA $146-154$ peptide and GM-CSF or autologous DC pulsed with PSA $_{146-154}$ peptide, and half of them showed PSAspecific immune response. ${ }^{169}$ In a phase I/II clinical trial, 12 patients with advanced PC were treated with four vaccinations of DC pulsed with PSA- and PSCAderived peptides. ${ }^{170}$ This vaccination approach induced DHT responses that was correlated with superior overall survival, and six patients had a stable disease and one patient showed a complete disappearance of lymphadenopathy. Multi-epitope immunotherapy strategy using DC loaded with antigenic peptides derived from PSCA, PAP, PSMA and PSA was used for treating six HLA$\mathrm{A} 2+$ patients with hormone-refractory PC. ${ }^{171}$ This approach was shown to be feasible and generated cellular antitumour response. In another phase I clinical trial, eight patients with hormone-refractory $P C$ received four vaccinations with DC loaded with a cocktail of HLA-A2-restricted peptides derived from PSA, PSMA, surviving, prostein and transient receptor potential p8. ${ }^{172}$ It is suggested that vaccination with a cocktail of peptides derived from different antigens might be superior treatment modality due to the genetic and biologic heterogeneity of PC. ${ }^{172}$

In a different vaccination approach targeting PAP (Dendreon Corp, Seattle, WA, USA, formerly Activated Cell Therapy), in association with the Mayo Clinic, developed the DC therapy APC8015 (Provenge) for the potential treatment of hormone-refractory PC. In this approach, DC were isolated from patients with hormonerefractory metastatic $\mathrm{PC}$, loaded ex vivo with a recombinant fusion protein consisting of PAP linked to GM-CSF (designated PA2024), and reinfused into patients. ${ }^{173}$ Thirteen patients received two infusions, one month apart, followed by three subcutaneous monthly doses of PA2024 fusion protein without cells. From 12 evaluable patients, concentrations of PSA decreased by more than half over the course of therapy in three patients. In all patients, $\mathrm{T}$ cells drawn after infusions were stimulated in vitro by PAP and GM-CSF, demonstrating broken immune tolerance against these normal proteins. Small et al. ${ }^{174}$ also used DC loaded with PA2024 fusion protein to treat patients with hormone-refractory PC. Thirty-one patients received three monthly infusions of Provenge with a final boost at 24 months. The vaccine was well

tolerated. All patients developed T-cell proliferative responses against PA2024 fusion protein, whereas 38\% of patients developed responses against native PAP protein. T cells drawn after therapy (but not before) were able to secrete IFN- $\gamma$. Three patients had at least a $50 \%$ decrease in PSA level, and another three patients had 25-49\% decreases. More recently, a phase II clinical trial using Provenge in patients with metastatic androgen-resistant PC was completed. ${ }^{175}$ Twenty-one patients were involved and two of them exhibited a transient 25$50 \%$ decrease in PSA level. Interestingly and for a third patient, PSA level dropped from $221 \mathrm{ng} / \mathrm{ml}$ at baseline to undetectable levels and has remained so for more than 4 years. Using such a mode of immunotherapy, a recombinant tumour-antigen fusion protein was used rather than peptides, and the use of the whole protein means that eligibility is not restricted to particular HLA types. Two recent trials with Provenge alone or combined with a recombinant antibody against vascular endothelial growth factor (bevacizumab) have been reported for treating patients with hormone-sensitive PC with serologic progression after definitive local therapy, inducing immune responses and modulating PSA levels. ${ }^{176,177}$ Provenge is the first immunotherapy modality that has shown a benefit and an overall survival advantage in patients with metastatic hormone-refractory PC. ${ }^{178}$ In another trial, 21 patients with metastatic PC were vaccinated with DC pulsed with a xenogeneic homologue of PAP (mouse PAP). ${ }^{179}$ Eleven patients developed T-cell proliferation with IFN- $\gamma$ secretion, whereas six patients had evidence of a stable disease.

\section{Whole-tumour cell vaccines}

There are some advantages for using whole-tumour cells as cancer vaccines. The polyvalent nature of this immunotherapy strategy allows processing and presentation of different TAA simultaneously through a variety of MHC haplotypes, and provides both MHC class I and II epitopes; leading to diverse immune responses mediated by activated $\mathrm{CD} 8^{+}$and $\mathrm{CD} 4{ }^{+}$T-cell effectors. This approach also limits the ability of tumour cells to evade immune recognition through loss or mutation of target antigen as in the case of one-peptide vaccines, or expression of the antigen in only a fraction of cancer cells. ${ }^{180}$ In addition, it has been shown that intact proteins, rather than exogenous or endogenous peptides or heat shock protein/peptide complexes, represent the major source of cross-priming antigens that are transferred from APCs. ${ }^{181}$

Clinical trials using irradiated autologous wholetumour PC vaccines were initiated following demonstrating their efficiency in preclinical animal models of PC. ${ }^{182}$ Autologous PC vaccines were initially used for treating eight PC patients in a phase I clinical trial. ${ }^{183} \mathrm{PC}$ cells collected from patients at surgery were established in cultures and genetically modified to produce high levels of GM-CSF via transduction with the replicationdefective retrovirus containing a cDNA encoding GMCSF gene. The vaccine cells were then lethally irradiated and between 3 and 6 vaccination cycles were intradermally injected into each patient. This study showed the safety of this vaccination approach and elicited both $\mathrm{T}$ - and B-cell immune responses to human PC. However, 
a sufficient number of cells could not be generated for 3 out of 11 patients due to technical difficulties. Although autologous human PC cells are the best source of antigen as they are self-derived, the technical difficulties of establishing and maintaining these cells ex vivo, and labour intensity due to individualized preparation of cancer vaccine represent major limitations for their potential use in clinical trials. ${ }^{184}$ On the other hand, using well-characterized allogeneic cell lines provides a potentially unlimited source of tumour for several vaccinations. Therefore, investigators have shifted their focus of research to clinical trials using allogeneic, rather than autologous, tumour vaccines.

In a phase I/II study, 60 patients with hormonerefractory PC received allogeneic whole-cell PC vaccine in combination with the immunostimulant Mycobacterium vaccae. ${ }^{184}$ The vaccine was safe, well tolerated and generated immune responses without showing a significant decrease in PSA level. PC vaccine GVAX (Cell Genesys, South San Francisco, CA, USA) is a mixture of irradiated PC cell lines PC-3 and LNCaP genetically engineered to secrete GM-CSF. In this vaccine, cell lines work as the source of tumour antigens and GM-CSF as the vaccine adjuvant. Cell Genesys has performed five clinical trials of GVAX in more than 200 patients with recurrent or metastatic PC, as summarized by Simons and Sacks. ${ }^{180}$ GVAX was demonstrated to be safe and to break immune tolerance against PC. Multi-institutional phase III trial of GVAX is in progress to evaluate the impact of allogeneic PC vaccine on time to progression (TTP) and overall survival in patients with hormonerefractory PC. ${ }^{180}$ A different allogeneic whole-cell vaccine composed of irradiated prostate cell lines OnyCap23, LNCaP and P4E6 demonstrated a decreased PSA velocity in 11 of 26 patients with HRPC and a longer median TTP (58 weeks), compared with other studies (28 weeks). ${ }^{185}$ Another approach using a xenogeneic tissue vaccine has recently been shown to stimulate protective immunity against human PC cells. ${ }^{186}$

\section{References}

1 Chamberlain RS, Kaufman H. Innovations and strategies for the development of anticancer vaccines. Expert Opin Pharmacother 2000; 1: 603-614.

2 Rosenberg SA, Lotze MT, Muul LM, Leitman S, Chang AE, Ettinghausen SE et al. Observations on the systemic administration of autologous lymphokine-activated killer cells and recombinant interleukin-2 to patients with metastatic cancer. $N$ Engl J Med 1985; 313: 1485-1492.

3 Blattman JN, Greenberg PD. Cancer immunotherapy: a treatment for the masses. Science 2004; 305: 200-205.

4 Shankaran V, Ikeda H, Bruce AT, White JM, Swanson PE, Old LJ et al. IFNgamma and lymphocytes prevent primary tumour development and shape tumour immunogenicity. Nature 2001; 410: 1107-1111.

5 Rosenberg SA. Shedding light on immunotherapy for cancer. $N$ Engl J Med 2004; 350: 1461-1463.

6 Inaba K, Young JW, Steinman RM. Direct activation of CD8+ cytotoxic T lymphocytes by dendritic cells. J Exp Med 1987; 166: 182-194.

7 McCoy KD, Hermans IF, Fraser JH, Le Gros G, Ronchese F. Cytotoxic T lymphocyte-associated antigen 4 (CTLA-4) can regulate dendritic cell-induced activation and cytotoxicity of CD8(+) T cells independently of CD4(+) T cell help. J Exp Med 1999; 189: 1157-1162.
8 Young JW, Steinman RM. Dendritic cells stimulate primary human cytolytic lymphocyte responses in the absence of CD4+ helper T cells. J Exp Med 1990; 171: 1315-1332.

9 Macatonia SE, Taylor PM, Knight SC, Askonas BA. Primary stimulation by dendritic cells induces antiviral proliferative and cytotoxic T cell responses in vitro. J Exp Med 1989; 169: 1255-1264.

10 Mehta-Damani A, Markowicz S, Engleman EG. Generation of antigen-specific CD8+ CTLs from naive precursors. I Immunol 1994; 153: 996-1003.

11 Banchereau J, Briere F, Caux C, Davoust J, Lebecque S, Liu YJ et al. Immunobiology of dendritic cells. Annu Rev Immunol 2000a; 18: 767-811.

12 Bennett SR, Carbone FR, Karamalis F, Miller JF, Heath WR. Induction of a CD8+ cytotoxic T lymphocyte response by crosspriming requires cognate CD4+ T cell help. J Exp Med 1997; 186: 65-70.

13 Bennett SR, Carbone FR, Karamalis F, Flavell RA, Miller JF, Heath WR. Help for cytotoxic-T-cell responses is mediated by CD40 signalling. Nature 1998; 393: 478-480.

14 Schoenberger SP, Toes RE, van der Voort EI, Offringa R, Melief CJ. T-cell help for cytotoxic $\mathrm{T}$ lymphocytes is mediated by CD40-CD40L interactions. Nature 1998; 393: 480-483.

15 Ridge JP, Di Rosa F, Matzinger P. A conditioned dendritic cell can be a temporal bridge between a CD4+ T-helper and a T-killer cell. Nature 1998; 393: 474-478.

16 Jefford M, Maraskovsky E, Cebon J, Davis ID. The use of dendritic cells in cancer therapy. Lancet Oncol 2001; 2: 343-353.

17 Alegre ML, Frauwirth KA, Thompson CB. T-cell regulation by CD28 and CTLA-4. Nat Rev Immunol 2001; 1: 220-228.

18 Freeman GJ, Boussiotis VA, Anumanthan A, Bernstein GM, Ke XY, Rennert PD et al. B7-1 and B7-2 do not deliver identical costimulatory signals, since B7-2 but not B7-1 preferentially costimulates the initial production of IL-4. Immunity 1995; 2: 523-532.

19 Kuchroo VK, Das MP, Brown JA, Ranger AM, Zamvil SS, Sobel RA et al. B7-1 and B7-2 costimulatory molecules activate differentially the Th1/Th2 developmental pathways: application to autoimmune disease therapy. Cell 1995; 80: 707-718.

20 Burnet FM. The concept of immunological surveillance. Prog Exp Tumor Res 1970; 13: 1-27.

21 Dunn GP, Bruce AT, Ikeda H, Old LJ, Schreiber RD. Cancer immunoediting: from immunosurveillance to tumor escape. Nat Immunol 2002; 3: 991-998.

22 Stutman O. Chemical carcinogenesis in nude mice: comparison between nude mice from homozygous matings and heterozygous matings and effect of age and carcinogen dose. J Natl Cancer Inst 1979; 62: 353-358.

23 Ikehara S, Pahwa RN, Fernandes G, Hansen CT, Good RA. Functional T cells in athymic nude mice. Proc Natl Acad Sci USA 1984; 81: 886-888.

24 Maleckar JR, Sherman LA. The composition of the $\mathrm{T}$ cell receptor repertoire in nude mice. J Immunol 1987; 138: 38733876 .

25 McClain KL. Immunodeficiency states and related malignancies. Cancer Treat Res 1997; 92: 39-61.

26 Dunn GP, Old LJ, Schreiber RD. The three Es of cancer immunoediting. Annu Rev Immunol 2004b; 22: 329-360.

27 Kaplan DH, Shankaran V, Dighe AS, Stockert E, Aguet M, Old LJ et al. Demonstration of an interferon gamma-dependent tumor surveillance system in immunocompetent mice. Proc Natl Acad Sci USA 1998; 95: 7556-7561.

28 Street SE, Trapani JA, MacGregor D, Smyth MJ. Suppression of lymphoma and epithelial malignancies effected by interferon gamma. I Exp Med 2002; 196: 129-134.

29 Zhang L, Conejo-Garcia JR, Katsaros D, Gimotty PA, Massobrio $\mathrm{M}$, Regnani $\mathrm{G}$ et al. Intratumoral $\mathrm{T}$ cells, recurrence, and survival in epithelial ovarian cancer. $N$ Engl J Med 2003; 348: 203-213.

30 Dunn GP, Old LJ, Schreiber RD. The three Es of cancer immunoediting. Annu Rev Immunol 2004b; 22: 329-360. 
31 Greenberg PD. Adoptive T cell therapy of tumors: mechanisms operative in the recognition and elimination of tumor cells. Adv Immunol 1991; 49: 281-355.

32 Van der Bruggen P, Traversari C, Chomez P, Lurquin C, De Plaen E, Van den EB et al. A gene encoding an antigen recognized by cytolytic $\mathrm{T}$ lymphocytes on a human melanoma. Science 1991; 254: 1643-1647.

33 Kawakami Y, Eliyahu S, Delgado CH, Robbins PF, Sakaguchi K, Appella $\mathrm{E}$ et al. Identification of a human melanoma antigen recognized by tumor-infiltrating lymphocytes associated with in vivo tumor rejection. Proc Natl Acad Sci USA 1994; 91: 6458-6462.

34 chultze JL, Vonderheide RH. From cancer genomics to cancer immunotherapy: toward second-generation tumor antigens. Trends Immunol 2001; 22: 516-523.

35 Brichard V, Van Pel A, Wolfel T, Wolfel C, De Plaen E, Lethe B et al. The tyrosinase gene codes for an antigen recognized by autologous cytolytic T lymphocytes on HLA-A2 melanomas. J Exp Med 1993; 178: 489-495.

36 De Plaen E, Lurquin C, Lethe B, van der BP, Brichard V, Renauld JC et al. Identification of genes coding for tumor antigens recognized by cytolytic T lymphocytes. Methods 1997; 12: $125-142$.

37 Rosenberg SA. A new era for cancer immunotherapy based on the genes that encode cancer antigens. Immunity 1999a; 10: 281-287.

38 Cox AL, Skipper J, Chen Y, Henderson RA, Darrow TL, Shabanowitz $\mathrm{J}$ et al. Identification of a peptide recognized by five melanoma-specific human cytotoxic T cell lines. Science 1994; 264: 716-719.

39 Hunt DF, Henderson RA, Shabanowitz J, Sakaguchi K, Michel $\mathrm{H}$, Sevilir $\mathrm{N}$ et al. Characterization of peptides bound to the class I MHC molecule HLA-A2.1 by mass spectrometry. Science 1992; 255: 1261-1263.

40 Fisk B, Blevins TL, Wharton JT, Ioannides CG. Identification of an immunodominant peptide of HER-2/neu protooncogene recognized by ovarian tumor-specific cytotoxic $\mathrm{T}$ lymphocyte lines. J Exp Med 1995; 181: 2109-2117.

41 Kawashima I, Hudson SJ, Tsai V, Southwood S, Takesako K, Appella E et al. The multi-epitope approach for immunotherapy for cancer: identification of several CTL epitopes from various tumor-associated antigens expressed on solid epithelial tumors. Hum Immunol 1998; 59: 1-14.

42 Tureci O, Sahin U, Pfreundschuh M. Serological analysis of human tumor antigens: molecular definition and implications. Mol Med Today 1997; 3: 342-349.

43 Renkvist N, Castelli C, Robbins PF, Parmiani G. A listing of human tumor antigens recognized by T cells. Cancer Immunol Immunother 2001; 50: 3-15.

44 Anichini A, Maccalli C, Mortarini R, Salvi S, Mazzocchi A, Squarcina $\mathrm{P}$ et al. Melanoma cells and normal melanocytes share antigens recognized by HLA-A2-restricted cytotoxic T cell clones from melanoma patients. J Exp Med 1993; 177: 989-998.

45 Kawashima I, Tsai V, Southwood S, Takesako K, Sette A, Celis E. Identification of HLA-A3-restricted cytotoxic T lymphocyte epitopes from carcinoembryonic antigen and HER-2/neu by primary in vitro immunization with peptide-pulsed dendritic cells. Cancer Res 1999; 59: 431-435.

46 Robbins PF, El Gamil M, Li YF, Kawakami Y, Loftus D, Appella $\mathrm{E}$ et al. A mutated beta-catenin gene encodes a melanomaspecific antigen recognized by tumor infiltrating lymphocytes. J Exp Med 1996; 183: 1185-1192.

47 Wolfel T, Hauer M, Schneider J, Serrano M, Wolfel C, Klehmann-Hieb E et al. A p16INK4a-insensitive CDK4 mutant targeted by cytolytic $\mathrm{T}$ lymphocytes in a human melanoma. Science 1995; 269: 1281-1284.

48 Topalian SL, Rivoltini L, Mancini M, Markus NR, Robbins PF, Kawakami Y et al. Human CD4+ T cells specifically recognize a shared melanoma-associated antigen encoded by the tyrosinase gene. Proc Natl Acad Sci USA 1994; 91: 9461-9465.

49 Rosenberg SA. Progress in human tumour immunology and immunotherapy. Nature 2001; 411: 380-384.

50 Boon T, Van den Eynde B. Tumour immunology. Curr Opin Immunol 2003; 15: 129-130.

51 Jager E, Ringhoffer M, Altmannsberger M, Arand M, Karbach J, Jager $\mathrm{D}$ et al. Immunoselection in vivo: independent loss of MHC class I and melanocyte differentiation antigen expression in metastatic melanoma. Int J Cancer 1997; 71: 142-147.

52 Schuler-Thurner B, Dieckmann D, Keikavoussi P, Bender A, Maczek $\mathrm{C}$, Jonuleit $\mathrm{H}$ et al. Mage-3 and influenza-matrix peptide-specific cytotoxic $\mathrm{T}$ cells are inducible in terminal stage HLA-A2.1+ melanoma patients by mature monocyte-derived dendritic cells. J Immunol 2000; 165: 3492-3496.

53 Fong L, Hou Y, Rivas A, Benike C, Yuen A, Fisher GA et al. Altered peptide ligand vaccination with Flt3 ligand expanded dendritic cells for tumor immunotherapy. Proc Natl Acad Sci USA 2001c; 98: 8809-8814.

54 Marchand M, van Baren N, Weynants P, Brichard V, Dreno B, Tessier $\mathrm{MH}$ et al. Tumor regressions observed in patients with metastatic melanoma treated with an antigenic peptide encoded by gene MAGE-3 and presented by HLA-A1. Int J Cancer 1999; 80: 219-230.

55 Nestle FO, Alijagic S, Gilliet M, Sun Y, Grabbe S, Dummer R et al. Vaccination of melanoma patients with peptide- or tumor lysate-pulsed dendritic cells. Nat Med 1998; 4: 328-332.

56 Rosenberg SA, Yang JC, Schwartzentruber DJ, Hwu P, Marincola FM, Topalian SL et al. Immunologic and therapeutic evaluation of a synthetic peptide vaccine for the treatment of patients with metastatic melanoma. Nat Med 1998; 4: 321-327.

57 Thurner B, Haendle I, Roder C, Dieckmann D, Keikavoussi P, Jonuleit $\mathrm{H}$ et al. Vaccination with mage-3A1 peptidepulsed mature, monocyte-derived dendritic cells expands specific cytotoxic $\mathrm{T}$ cells and induces regression of some metastases in advanced stage IV melanoma. J Exp Med 1999; 190: 1669-1678.

58 Rosenberg SA. A new era of cancer immunotherapy: converting theory to performance. CA Cancer J Clin 1999b; 49: 70-73, 65.

59 Ochsenbein AF, Klenerman P, Karrer U, Ludewig B, Pericin M, Hengartner $\mathrm{H}$ et al. Immune surveillance against a solid tumor fails because of immunological ignorance. Proc Natl Acad Sci USA 1999; 96: 2233-2238.

60 Janeway CA, Travers P, Walport M, Shlomchik M. Manipulation of the immune response. In: Bushell G (ed) Immunobiology: The Immune System in Health and Disease. Garland Publishing: London, 2001, pp 553-596.

61 Sanda MG, Restifo NP, Walsh JC, Kawakami Y, Nelson WG, Pardoll DM et al. Molecular characterization of defective antigen processing in human prostate cancer. J Natl Cancer Inst 1995; 87: 280-285.

62 Soong TW, Hui KM. Regulation of the expression of major histocompatibility complex class I genes in human colorectal cancer. Cancer Detect Prev 1991; 15: 231-239.

63 Zheng P, Sarma S, Guo Y, Liu Y. Two mechanisms for tumor evasion of preexisting cytotoxic T-cell responses: lessons from recurrent tumors. Cancer Res 1999; 59: 3461-3467.

64 Chen L, Linsley PS, Hellstrom KE. Costimulation of T cells for tumor immunity. Immunol Today 1993; 14: 483-486.

65 Gabrilovich D, Ishida T, Oyama T, Ran S, Kravtsov V, Nadaf S et al. Vascular endothelial growth factor inhibits the development of dendritic cells and dramatically affects the differentiation of multiple hematopoietic lineages in vivo. Blood 1998; 92: $4150-4166$.

66 Oyama T, Ran S, Ishida T, Nadaf S, Kerr L, Carbone DP et al. Vascular endothelial growth factor affects dendritic cell maturation through the inhibition of nuclear factor-kappa B activation in hemopoietic progenitor cells. J Immunol 1998; 160: 1224-1232.

67 Chaux P, Favre N, Martin M, Martin F. Tumor-infiltrating dendritic cells are defective in their antigen-presenting function and inducible B7 expression in rats. Int J Cancer 1997; 72: 619-624. 
68 Gabrilovich DI, Ciernik IF, Carbone DP. Dendritic cells in antitumor immune responses. I. Defective antigen presentation in tumor-bearing hosts. Cell Immunol 1996; 170: 101-110.

69 Enk AH, Jonuleit H, Saloga J, Knop J. Dendritic cells as mediators of tumor-induced tolerance in metastatic melanoma. Int J Cancer 1997; 73: 309-316.

70 Gabrilovich DI, Corak J, Ciernik IF, Kavanaugh D, Carbone DP. Decreased antigen presentation by dendritic cells in patients with breast cancer. Clin Cancer Res 1997; 3: 483-490.

71 Troy AJ, Summers KL, Davidson PJ, Atkinson CH, Hart DN. Minimal recruitment and activation of dendritic cells within renal cell carcinoma. Clin Cancer Res 1998; 4: 585-593.

72 Fortis C, Foppoli M, Gianotti L, Galli L, Citterio G, Consogno G et al. Increased interleukin-10 serum levels in patients with solid tumours. Cancer Lett 1996; 104: 1-5.

73 Beck C, Schreiber H, Rowley D. Role of TGF-beta in immuneevasion of cancer. Microsc Res Tech 2001; 52: 387-395.

74 Yang L, Yamagata N, Yadav R, Brandon S, Courtney RL, Morrow JD et al. Cancer-associated immunodeficiency and dendritic cell abnormalities mediated by the prostaglandin EP2 receptor. J Clin Invest 2003; 111: 727-735.

75 Strand S, Hofmann WJ, Hug H, Muller M, Otto G, Strand D et al. Lymphocyte apoptosis induced by CD95 (APO-1/Fas) ligand-expressing tumor cells-a mechanism of immune evasion? Nat Med 1996; 2: 1361-1366.

76 Wang HY, Lee DA, Peng G, Guo Z, Li Y, Kiniwa Y et al. Tumorspecific human $\mathrm{CD} 4+$ regulatory $\mathrm{T}$ cells and their ligands: implications for immunotherapy. Immunity 2004; 20: 107-118.

77 Miller AM, Lundberg K, Ozenci V, Banham AH, Hellstrom M, Egevad L et al. CD4+CD25high T cells are enriched in the tumor and peripheral blood of prostate cancer patients. J Immunol 200; 177: 7398-7405.

78 Clay TM, Hobeika AC, Mosca PJ, Lyerly HK, Morse MA. Assays for monitoring cellular immune responses to active immunotherapy of cancer. Clin Cancer Res 2001; 7: 1127-1135.

79 Altman JD, Moss PA, Goulder PJ, Barouch DH, McHeyzerWilliams MG, Bell JI et al. Phenotypic analysis of antigenspecific T lymphocytes. Science 1996; 274: 94-96.

80 Gratama JW, van Esser JW, Lamers CH, Tournay C, Lowenberg $\mathrm{B}$, Bolhuis RL et al. Tetramer-based quantification of cytomegalovirus (CMV)-specific CD8+ $\mathrm{T}$ lymphocytes in T-celldepleted stem cell grafts and after transplantation may identify patients at risk for progressive CMV infection. Blood 2001; 98: 1358-1364.

81 Keenan RD, Ainsworth J, Khan N, Bruton R, Cobbold M, Assenmacher $\mathrm{M}$ et al. Purification of cytomegalovirus-specific CD8 $\mathrm{T}$ cells from peripheral blood using HLA-peptide tetramers. Br J Haematol 2001; 115: 428-434.

82 Dunbar PR, Ogg GS, Chen J, Rust N, van der BP, Cerundolo V. Direct isolation, phenotyping and cloning of low-frequency antigen-specific cytotoxic $\mathrm{T}$ lymphocytes from peripheral blood. Curr Biol 1998; 8: 413-416.

83 Lee KH, Wang E, Nielsen MB, Wunderlich J, Migueles S, Connors $\mathrm{M}$ et al. Increased vaccine-specific $\mathrm{T}$ cell frequency after peptide-based vaccination correlates with increased susceptibility to in vitro stimulation but does not lead to tumor regression

J Immunol 1999; 163: 6292-6300.

84 Pittet MJ, Valmori D, Dunbar PR, Speiser DE, Lienard D, Lejeune $\mathrm{F}$ et al. High frequencies of naive Melan-A/MART-1specific CD8(+) $\mathrm{T}$ cells in a large proportion of human histocompatibility leukocyte antigen (HLA)-A2 individuals. J Exp Med 1999; 190: 705-715.

85 Romero P, Dunbar PR, Valmori D, Pittet M, Ogg GS, Rimoldi D et al. Ex vivo staining of metastatic lymph nodes by class I major histocompatibility complex tetramers reveals high numbers

of antigen-experienced tumor-specific cytolytic T lymphocytes. J Exp Med 1998; 188: 1641-1650.

86 Givan AL, Fisher JL, Waugh M, Ernstoff MS, Wallace PK. A flow cytometric method to estimate the precursor frequencies of cells proliferating in response to specific antigens. J Immunol Methods 1999; 230: 99-112.

87 Hatam L, Schuval S, Bonagura VR. Flow cytometric analysis of natural killer cell function as a clinical assay. Cytometry 1994; 16: 59-68.

88 Wilkinson RW, Lee-MacAry AE, Davies D, Snary D, Ross EL. Antibody-dependent cell-mediated cytotoxicity: a flow cytometry-based assay using fluorophores. J Immunol Methods 2001; 258: 183-191.

89 Elkord E, Williams PE, Kynaston H, Rowbottom AW. Differential CTLs specific for prostate-specific antigen in healthy donors and patients with prostate cancer. Int Immunol 2005; 17: 1315-1325.

90 Carson RT, Vignali DA. Simultaneous quantitation of 15 cytokines using a multiplexed flow cytometric assay. J Immunol Methods 1999; 227: 41-52.

91 Czerkinsky C, Andersson G, Ekre HP, Nilsson LA, Klareskog L, Ouchterlony O. Reverse ELISPOT assay for clonal analysis of cytokine production. I. Enumeration of gamma-interferonsecreting cells. J Immunol Methods 1988; 110: 29-36.

92 Schmittel A, Keilholz U, Scheibenbogen C. Evaluation of the interferon-gamma ELISPOT-assay for quantification of peptide specific $\mathrm{T}$ lymphocytes from peripheral blood. I Immunol Methods 1997; 210: 167-174.

93 Maino VC, Picker LJ. Identification of functional subsets by flow cytometry: intracellular detection of cytokine expression. Cytometry 1998; 34: 207-215.

94 Jemal A, Siegel R, Ward E, Murray T, Xu J, Smigal C et al. Cancer statistics, 2006. CA Cancer J Clin 2006; 56: 106-130.

95 Cancer Research UK. Prostate CancerStats 2002. Cancer Research UK: London, 2002

96 Jones GW, Mettlin C, Murphy GP, Guinan P, Herr HW, Hussey $\mathrm{DH}$ et al. Patterns of care for carcinoma of the prostate gland: results of a national survey of 1984 and 1990. J Am Coll Surg 1995; 180: 545-554

97 Selley S, Donovan J, Faulkner A, Coast J, Gillatt D. Diagnosis, management and screening of early localised prostate cancer. Health Technol Assess 1997; 1: i1-i96.

98 Elo JP, Visakorpi T. Molecular genetics of prostate cancer. Ann Med 2001; 33: 130-141.

99 Jemal A, Tiwari RC, Murray T, Ghafoor A, Samuels A, Ward E et al. Cancer statistics, 2004. CA Cancer J Clin 2004; 54: 8-29.

100 Kolonel LN, Nomura AM, Cooney RV. Dietary fat and prostate cancer: current status. J Natl Cancer Inst 1999; 91: 414-428.

101 Guidelines on the management of prostate cancer. A document for local expert groups in the United Kingdom preparing prostate management policy documents. The Royal College of Radiologists' Clinical Oncology Information Network. British Association of Urological Surgeons. BJU Int 1999; 84: 987-1014.

102 Ablin RJ, Soanes WA, Bronson P, Witebsky E. Precipitating antigens of the normal human prostate. J Reprod Fertil 1970; 22: 573-574.

103 Hara M, Koyanagi Y, Inoue T, Fukuyama T. [Some physicochemical characteristics of '-seminoprotein', an antigenic component specific for human seminal plasma. Forensic immunological study of body fluids and secretion. VII]. Nippon Hoigaku Zasshi 1971; 25: 322-324.

104 Wang MC, Valenzuela LA, Murphy GP, Chu TM. Purification of a human prostate specific antigen. Invest Urol 1979; 17: 159-163.

105 Riegman PH, Vlietstra RJ, Suurmeijer L, Cleutjens CB, Trapman J. Characterization of the human kallikrein locus. Genomics 1992; 14: 6-11.

106 Yousef GM, Diamandis EP. The expanded human kallikrein gene family: locus characterization and molecular cloning of a new member, KLK-L3 (KLK9). Genomics 2000; 65: 184-194.

107 Yousef GM, Diamandis EP. The new human tissue kallikrein gene family: structure, function, and association to disease. Endocr Rev 2001; 22: 184-204.

108 Henttu P, Vihko P. cDNA coding for the entire human prostate specific antigen shows high homologies to the human tissue 
kallikrein genes. Biochem Biophys Res Commun 1989; 160: 903-910.

109 Henttu P, Vihko P. Prostate-specific antigen and human glandular kallikrein: two kallikreins of the human prostate. Ann Med 1994; 26: 157-164.

110 Lundwall A, Lilja H. Molecular cloning of human prostate specific antigen cDNA. FEBS Lett 1987; 214: 317-322.

111 Schaller J, Akiyama K, Tsuda R, Hara M, Marti T, Rickli EE. Isolation, characterization and amino-acid sequence of gammaseminoprotein, a glycoprotein from human seminal plasma. Eur J Biochem 1987; 170: 111-120.

112 Wang MC, Papsidero LD, Kuriyama M, Valenzuela LA, Murphy GP, Chu TM. Prostate antigen: a new potential marker for prostatic cancer. Prostate 1981; 2: 89-96.

113 Kelloff GJ, Coffey DS, Chabner BA, Dicker AP, Guyton KZ, Nisen PD et al. Prostate-specific antigen doubling time as a surrogate marker for evaluation of oncologic drugs to treat prostate cancer. Clin Cancer Res 2004; 10: 3927-3933.

114 vZhang WM, Leinonen J, Kalkkinen N, Dowell B, Stenman UH. Purification and characterization of different molecular forms of prostate-specific antigen in human seminal fluid. Clin Chem 1995; 41: 1567-1573.

115 Lilja H, Oldbring J, Rannevik G, Laurell CB. Seminal vesiclesecreted proteins and their reactions during gelation and liquefaction of human semen. J Clin Invest 1987; 80: 281-285.

116 Giai M, Yu H, Roagna R, Ponzone R, Katsaros D, Levesque MA et al. Prostate-specific antigen in serum of women with breast cancer. Br J Cancer 1995; 72: 728-731.

117 Melegos DN, Diamandis EP. Is prostate-specific antigen present in female serum? Clin Chem 1998; 44: 691-692.

$118 \mathrm{Yu} \mathrm{H}$, Diamandis EP. Measurement of serum prostate specific antigen levels in women and in prostatectomized men with an ultrasensitive immunoassay technique. J Urol 1995; 153: 1004-1008.

119 Tepper SL, Jagirdar J, Heath D, Geller SA. Homology between the female paraurethral (Skene's) glands and the prostate. Immunohistochemical demonstration. Arch Pathol Lab Med 1984; 108: 423-425.

120 Zaviacic M, Ablin RJ. The female prostate and prostate-specific antigen. Immunohistochemical localization, implications of this prostate marker in women and reasons for using the term prostate in the human female. Histol Histopathol 2000; 15: 131-142.

121 Barry MJ. Clinical practice. Prostate-specific-antigen testing for early diagnosis of prostate cancer. $N$ Engl J Med 2001; 344: 1373-1377.

122 Hamdy FC. Prognostic and predictive factors in prostate cancer. Cancer Treat Rev 2001; 27: 143-151.

123 Ryan CJ, Small EJ. Advances in prostate cancer. Curr Opin Oncol 2004; 16: 242-246.

124 Babaian RJ, Johnston DA, Naccarato W, Ayala A, Bhadkamkar VA, Fritsche Jr HH. The incidence of prostate cancer in a screening population with a serum prostate specific antigen between 2.5 and $4.0 \mathrm{ng} / \mathrm{ml}$ : relation to biopsy strategy. J Urol 2001; 165: 757-760.

125 Catalona WJ, Smith DS, Ornstein DK. Prostate cancer detection in men with serum PSA concentrations of 2.6 to $4.0 \mathrm{ng} / \mathrm{ml}$ and benign prostate examination. Enhancement of specificity with free PSA measurements. JAMA 1997; 277: 1452-1455.

126 Ornstein DK, Pruthi RS. Prostate-specific antigen. Expert Opin Pharmacother 2000; 1: 1399-1411.

127 Pruthi RS. The dynamics of prostate-specific antigen in benign and malignant diseases of the prostate. BJU Int 2000; 86: 652-658.

128 Carter HB, Morrell CH, Pearson JD, Brant LJ, Plato CC, Metter EJ et al. Estimation of prostatic growth using serial prostatespecific antigen measurements in men with and without prostate disease. Cancer Res 1992; 52: 3323-3328.

129 D'Amico AV, Chen MH, Roehl KA, Catalona WJ. Preoperative PSA velocity and the risk of death from prostate cancer after radical prostatectomy. N Engl J Med 2004; 351: 125-135.

130 Johnston BJ. Clinical effects of Coley's toxin. I. A controlled study. Cancer Chemother Rep 1962; 21: 19-41.

131 Freiha FS, Bagshaw MA. Carcinoma of the prostate: results of post-irradiation biopsy. Prostate 1984; 5: 19-25.

132 Moul JW. Prostate specific antigen only progression of prostate cancer. J Urol 2000; 163: 1632-1642.

133 Schellhammer PF, el Mahdi AM, Higgins EM, Schultheiss TE, Ladaga LE, Babb TJ. Prostate biopsy after definitive treatment by interstitial 125iodine implant or external beam radiation therapy. J Urol 1987; 137: 897-901.

134 Vesalainen S, Lipponen P, Talja M, Syrjanen K. Histological grade, perineural infiltration, tumour-infiltrating lymphocytes and apoptosis as determinants of long-term prognosis in prostatic adenocarcinoma. Eur J Cancer 1994; 30A: 1797-1803.

135 van Parijs L, Abbas AK. Homeostasis and self-tolerance in the immune system: turning lymphocytes off. Science 1998; 280: 243-248.

136 Oesterling JE. Prostate specific antigen: a critical assessment of the most useful tumor marker for adenocarcinoma of the prostate. J Urol 1991; 145: 907-923.

137 Papsidero LD, Kuriyama M, Wang MC, Horoszewicz J, Leong SS, Valenzuela L et al. Prostate antigen: a marker for human prostate epithelial cells. J Natl Cancer Inst 1981; 66: 37-42.

138 Xue BH, Zhang Y, Sosman JA, Peace DJ. Induction of human cytotoxic $\mathrm{T}$ lymphocytes specific for prostate-specific antigen. Prostate 1997; 30: 73-78.

139 Correale P, Walmsley K, Nieroda C, Zaremba S, Zhu M, Schlom $\mathrm{J}$ et al. In vitro generation of human cytotoxic $\mathrm{T}$ lymphocytes specific for peptides derived from prostate-specific antigen. J Natl Cancer Inst 1997; 89: 293-300.

140 Elkord E, Rowbottom AW, Kynaston H, Williams PE. Correlation between CD8+ T cells specific for prostate-specific antigen and level of disease in patients with prostate cancer. Clin Immunol 2006; 120: 91-98.

141 Correale P, Walmsley K, Zaremba S, Zhu M, Schlom J, Tsang KY. Generation of human cytolytic T lymphocyte lines directed against prostate-specific antigen (PSA) employing a PSA oligoepitope peptide. J Immunol 1998; 161: 3186-3194.

142 Terasawa H, Tsang KY, Gulley J, Arlen P, Schlom J. Identification and characterization of a human agonist cytotoxic T-lymphocyte epitope of human prostate-specific antigen. Clin Cancer Res 2002; 8: 41-53.

143 Alexander RB, Brady F, Leffell MS, Tsai V, Celis E. Specific T cell recognition of peptides derived from prostate-specific antigen in patients with prostate cancer. Urology 1998; 51: 150-157.

144 Chakraborty NG, Stevens RL, Mehrotra S, Laska E, Taxel P, Sporn JR et al. Recognition of PSA-derived peptide antigens by $\mathrm{T}$ cells from prostate cancer patients without any prior stimulation. Cancer Immunol Immunother 2003; 52: 497-505.

145 Sanda MG, Smith DC, Charles LG, Hwang C, Pienta KJ, Schlom $\mathrm{J}$ et al. Recombinant vaccinia-PSA (PROSTVAC) can induce a prostate-specific immune response in androgen-modulated human prostate cancer. Urology 1999; 53: 260-266.

146 Eder JP, Kantoff PW, Roper K, Xu GX, Bubley GJ, Boyden J et al. A phase I trial of a recombinant vaccinia virus expressing prostate-specific antigen in advanced prostate cancer. Clin Cancer Res 2000; 6: 1632-1638.

147 Gulley J, Chen AP, Dahut W, Arlen PM, Bastian A, Steinberg SM et al. Phase I study of a vaccine using recombinant vaccinia virus expressing PSA (rV-PSA) in patients with metastatic androgenindependent prostate cancer. Prostate 2002; 53: 109-117.

148 Meidenbauer N, Harris DT, Spitler LE, Whiteside TL. Generation of PSA-reactive effector cells after vaccination with a PSAbased vaccine in patients with prostate cancer. Prostate 2000; 43: $88-100$.

149 Israeli RS, Powell CT, Fair WR, Heston WD. Molecular cloning of a complementary DNA encoding a prostate-specific membrane antigen. Cancer Res 1993; 53: 227-230.

$150 \mathrm{Lu}$ J, Celis E. Recognition of prostate tumor cells by cytotoxic $\mathrm{T}$ lymphocytes specific for prostate-specific membrane antigen. Cancer Res 2002; 62: 5807-5812. 
151 Tjoa B, Boynton A, Kenny G, Ragde H, Misrock SL, Murphy G. Presentation of prostate tumor antigens by dendritic cells stimulates T-cell proliferation and cytotoxicity. Prostate 1996; 28: 65-69.

152 Vihko P, Virkkunen P, Henttu P, Roiko K, Solin T, Huhtala ML. Molecular cloning and sequence analysis of cDNA encoding human prostatic acid phosphatase. FEBS Lett 1988; 236: 275-281.

153 Harada M, Matsueda S, Yao A, Ogata R, Noguchi M, Itoh K. Prostate-related antigen-derived new peptides having the capacity of inducing prostate cancer-reactive CTLs in HLAA2+ prostate cancer patients. Oncol Rep 2004; 12: 601-607.

154 Peshwa MV, Shi JD, Ruegg C, Laus R, van Schooten WC. Induction of prostate tumor-specific CD8+ cytotoxic T-lymphocytes in vitro using antigen-presenting cells pulsed with prostatic acid phosphatase peptide. Prostate 1998; 36: 129-138.

155 Reiter RE, Gu Z, Watabe T, Thomas G, Szigeti K, Davis E et al. Prostate stem cell antigen: a cell surface marker overexpressed in prostate cancer. Proc Natl Acad Sci USA 1998; 95: 1735-1740.

156 Dannull J, Diener PA, Prikler L, Furstenberger G, Cerny T, Schmid $\mathrm{U}$ et al. Prostate stem cell antigen is a promising candidate for immunotherapy of advanced prostate cancer. Cancer Res 2000; 60: 5522-5528.

157 Kiessling A, Schmitz M, Stevanovic S, Weigle B, Holig K, Fussel $\mathrm{M}$ et al. Prostate stem cell antigen: identification of immunogenic peptides and assessment of reactive CD8+ T cells in prostate cancer patients. Int J Cancer 2002; 102: 390-397.

158 Tjoa BA, Murphy GP. Development of dendritic-cell based prostate cancer vaccine. Immunol Lett 2000; 74: 87-93.

159 Curiel TJ, Curiel DT. Tumor immunotherapy: inching toward the finish line. J Clin Invest 2002; 109: 311-312.

160 Murphy G, Tjoa B, Ragde H, Kenny G, Boynton A. Phase I clinical trial: T-cell therapy for prostate cancer using autologous dendritic cells pulsed with HLA-A0201-specific peptides from prostate-specific membrane antigen. Prostate 1996; 29: 371-380.

161 Murphy GP, Tjoa BA, Simmons SJ, Ragde H, Rogers M, Elgamal A et al. Phase II prostate cancer vaccine trial: report of a study involving 37 patients with disease recurrence following primary treatment. Prostate 1999; 39: 54-59.

162 Tjoa BA, Erickson SJ, Bowes VA, Ragde H, Kenny GM, Cobb $\mathrm{OE}$ et al. Follow-up evaluation of prostate cancer patients infused with autologous dendritic cells pulsed with PSMA peptides. Prostate 1997; 32: 272-278.

163 Tjoa BA, Simmons SJ, Bowes VA, Ragde H, Rogers M, Elgamal A et al. Evaluation of phase I/II clinical trials in prostate cancer with dendritic cells and PSMA peptides. Prostate 1998; 36: 39-44.

164 Tjoa BA, Simmons SJ, Elgamal A, Rogers M, Ragde H, Kenny $\mathrm{GM}$ et al. Follow-up evaluation of a phase II prostate cancer vaccine trial. Prostate 1999; 40: 125-129.

165 Mincheff M, Tchakarov S, Zoubak S, Loukinov D, Botev C, Altankova I et al. Naked DNA and adenoviral immunizations for immunotherapy of prostate cancer: a phase I/II clinical trial. Eur Urol 2000; 38: 208-217.

166 Heiser A, Maurice MA, Yancey DR, Wu NZ, Dahm P, Pruitt SK et al. Induction of polyclonal prostate cancer-specific CTL using dendritic cells transfected with amplified tumor RNA. J Immunol 2001; 166: 2953-2960.

167 Heiser A, Coleman D, Dannull J, Yancey D, Maurice MA, Lallas $\mathrm{CD}$ et al. Autologous dendritic cells transfected with prostatespecific antigen RNA stimulate CTL responses against metastatic prostate tumors. J Clin Invest 2002; 109: 409-417.

168 Wolchok JD, Gregor PD, Nordquist LT, Slovin SF, Scher HI. DNA vaccines: an active immunization strategy for prostate cancer. Semin Oncol 2003; 30: 659-666.

169 Perambakam S, Hallmeyer S, Reddy S, Mahmud N, Bressler L, DeChristopher $\mathrm{P}$ et al. Induction of specific $\mathrm{T}$ cell immunity in patients with prostate cancer by vaccination with PSA146-154 peptide. Cancer Immunol Immunother 2006; 55: 1033-1042.
170 Thomas-Kaskel AK, Zeiser R, Jochim R, Robbel C, SchultzeSeemann W, Waller CF et al. Vaccination of advanced prostate cancer patients with PSCA and PSA peptide-loaded dendritic cells induces DTH responses that correlate with superior overall survival. Int J Cancer 2006; 119: 2428-2434.

171 Waeckerle-Men Y, Uetz-von Allmen E, Fopp M, von Moos R, Bohme C, Schmid HP et al. Dendritic cell-based multi-epitope immunotherapy of hormone-refractory prostate carcinoma. Cancer Immunol Immunother 2006; 55: 1524-1533.

172 Fuessel S, Meye A, Schmitz M, Zastrow S, Linne C, Richter K et al. Vaccination of hormone-refractory prostate cancer patients with peptide cocktail-loaded dendritic cells: results of a phase I clinical trial. Prostate 2006; 66: 811-821.

173 Burch PA, Breen JK, Buckner JC, Gastineau DA, Kaur JA, Laus RL et al. Priming tissue-specific cellular immunity in a phase I trial of autologous dendritic cells for prostate cancer. Clin Cancer Res 2000; 6: 2175-2182.

174 Small EJ, Fratesi P, Reese DM, Strang G, Laus R, Peshwa MV et al. Immunotherapy of hormone-refractory prostate cancer with antigen-loaded dendritic cells. J Clin Oncol 2000; 18: 3894-3903.

175 Burch PA, Croghan GA, Gastineau DA, Jones LA, Kaur JS, Kylstra JW et al. Immunotherapy (APC8015, Provenge) targeting prostatic acid phosphatase can induce durable remission of metastatic androgen-independent prostate cancer: a phase 2 trial. Prostate 2004; 60: 197-204.

176 Beinart G, Rini BI, Weinberg V, Small EJ. Antigen-presenting cells 8015 (Provenge) in patients with androgen-dependent, biochemically relapsed prostate cancer. Clin Prostate Cancer 2005; 4: 55-60.

177 Rini BI, Weinberg V, Fong L, Conry S, Hershberg RM, Small EJ. Combination immunotherapy with prostatic acid phosphatase pulsed antigen-presenting cells (Provenge) plus bevacizumab in patients with serologic progression of prostate cancer after definitive local therapy. Cancer 2006; 107: 67-74.

178 Lin AM, Hershberg RM, Small EJ. Immunotherapy for prostate cancer using prostatic acid phosphatase loaded antigen presenting cells. Urol Oncol 2006; 24: 434-441.

179 Fong L, Brockstedt D, Benike C, Breen JK, Strang G, Ruegg CL et al. Dendritic cell-based xenoantigen vaccination for prostate cancer immunotherapy. J Immunol 2001; 167: 7150-7156.

180 Simons JW, Sacks N. Granulocyte-macrophage colony-stimulating factor-transduced allogeneic cancer cellular immunotherapy: the GVAX vaccine for prostate cancer. Urol Oncol 2006; 24: 419-424.

181 Shen L, Rock KL. Cellular protein is the source of cross-priming antigen in vivo. Proc Natl Acad Sci USA 2004; 101: 3035-3040.

182 Vieweg J, Rosenthal FM, Bannerji R, Heston WD, Fair WR, Gansbacher B et al. Immunotherapy of prostate cancer in the Dunning rat model: use of cytokine gene modified tumor vaccines. Cancer Res 1994; 54: 1760-1765.

183 Simons JW, Mikhak B, Chang JF, DeMarzo AM, Carducci MA, Lim $\mathrm{M}$ et al. Induction of immunity to prostate cancer antigens: results of a clinical trial of vaccination with irradiated autologous prostate tumor cells engineered to secrete granulocyte-macrophage colony-stimulating factor using ex vivo gene transfer. Cancer Res 1999; 59: 5160-5168.

184 Eaton JD, Perry MJ, Nicholson S, Guckian M, Russell N, Whelan $\mathrm{M}$ et al. Allogeneic whole-cell vaccine: a phase I/II study in men with hormone-refractory prostate cancer. BJU Int 2002; 89: 19-26.

185 Michael A, Ball G, Quatan N, Wushishi F, Russell N, Whelan J et al. Delayed disease progression after allogeneic cell vaccination in hormone-resistant prostate cancer and correlation with immunologic variables. Clin Cancer Res 2005; 11: 4469-4478.

186 Suckow MA, Rosen ED, Wolter WR, Sailes V, Jeffrey R, Tenniswood M. Prevention of human PC-346C prostate cancer growth in mice by a xenogeneic tissue vaccine. Cancer Immunol Immunother 2007 (E-pub ahead of print). 